\title{
Length-weight and length-length relationship for three marine fish species of commercial importance from southwestern Atlantic Ocean coast
}

\author{
Fernanda G. Biolé ${ }^{1}$, Alejandra V. Volpedo ${ }^{1,2}$ \& Gustavo A. Thompson ${ }^{1}$ \\ ${ }^{1}$ CONICET, Universidad de Buenos Aires, Instituto de Investigaciones en Producción Animal (INPA) \\ Buenos Aires, Argentina \\ ${ }^{2}$ Centro de Estudios Transdisciplinarios del Agua (CETA), Facultad de Ciencias Veterinarias \\ Universidad de Buenos Aires, Argentina \\ Corresponding author: Alejandra V. Volpedo (avolpedo@gmail.com)
}

\begin{abstract}
Length-weight (LWR) and length-length (LLR) relationships were described for three marine fish species Odontesthes argentinensis (Valenciennes, 1835), Urophycis brasiliensis (Kaup, 1858) and Brevoortia aurea (Spix \& Agassiz, 1829) from the southwestern Atlantic Ocean coast, among sampling sites between 36 and $38^{\circ} \mathrm{S}$. These species have commercial importance in fisheries. Latitudinal change in LWR could suggest the existence of different subpopulations throughout their distribution ranges. A total of 2,167 specimens were collected between August 2015 and October 2018 using lift nets (mostly $10 \mathrm{~mm}$ mesh size) and fishing rods 100-200 m offshore. Both relationships were highly significant $(P<0.0001)$ for all species and produced robust coefficients of determination $\left(R^{2}>0.94\right)$. The latitudinal trend of $a$ and $b$ parameters of LWR showed different patterns for each species. This study provides a new maximum length for $B$. aurea and describes the variation of the regression parameters. New length-length relationships of these species were reported.
\end{abstract}

Keywords: Brevoortia aurea; Odontesthes argentinensis; Urophycis brasiliensis; morphometrics relationship; coastal fish; southern Atlantic

Length-weight relationship (LWR) and length-length relationship (LLR) are useful tools for fish ecology, fish resource assessment, and fisheries management (Froese, 2006). Different length measures of fishes are required for particular applications. Standard length (SL) may be useful as a principal length measure for scientific purposes because the total length (TL) is not always available (e.g., the tail was bitten off). On the other hand, the SL is more commonly used in fisheries management, such as defining minimum legal lengths for commercial and recreational fisheries. Therefore, reliable length-length relationships are required for data conversions.

The southwestern Atlantic Ocean coast is an important commercial, artisanal and recreational fishery area. Odontesthes argentinensis (Valenciennes, 1835), Urophycis brasiliensis (Kaup, 1858), and Brevoortia aurea (Spix \& Agassiz, 1829) are important in fisheries as transnational marine resources. $O$. argentinensis is a marine species distributed between
Rio de Janeiro, Brazil $\left(22^{\circ} \mathrm{S}\right)$, and Rawson, Argentina $\left(43^{\circ} \mathrm{S}\right)$ (Dyer, 2000; Di Dario et al., 2014). U. brasiliensis is a euryhaline species found in the western Atlantic between southern Brazil $\left(23^{\circ} \mathrm{S}\right)$ and southern Argentina (San Jorge Gulf; $45^{\circ}$ S) (Bovcon et al., 2011; Lemes et al., 2016). B. aurea is distributed between Bahia, Brazil $\left(22^{\circ} \mathrm{S}\right)$, and Bahia Blanca, Argentina $\left(39^{\circ} \mathrm{S}\right)$ (Segura \& Diaz de Astarloa, 2004). Despite these wide distributional ranges, most of LWR were reported for Brazil and the Uruguay coast, with very few studies for the Argentinean marine coast (Molina, 2012; Llompart et al., 2013; Solari et al., 2016). LWR are widely used to transform the survey data into estimates of the biomass, relevant information for modeling aquatic ecosystems (Froese, 2006). Also, spatial variation in length-weight relationships could be associated with the existence of different subpopulations of fish (Ma et al., 2017). This information is essential in fisheries science. Therefore, this study reports the length-weight relationships for the three

Corresponding editor: Leonardo Abitia 
species in diverse geographic coastal areas of southwestern Atlantic Ocean and analyses the variation of the regression parameters among sampling sites and seasons and tests for differences in parameter values along the latitudinal gradient.

Three fish species $(O$. argentinensis, $U$. brasiliensis, and $B$. aurea) were collected from the southwestern Atlantic Ocean coast, in north Argentinian waters (36$38^{\circ} \mathrm{S}$ ), between August 2015 and October 2018. Five sampling sites were selected: Samborombón Bay (SB), San Clemente del Tuyú (SCT), Lucila del Mar (LL), Villa Gesell (VG), and Mar del Plata (MdP) (Fig. 1). Samples were carried out overnight using lift nets (mostly $10 \mathrm{~mm}$ mesh size) and fishing rods 100-200 m offshore. Fish were identified up to the species level, according to Menni et al. (1984), Nelson (1994) and Segura \& Díaz de Astarloa (2004). For each specimen, $\mathrm{TL}$ and SL were measured to the nearest $0.1 \mathrm{~cm}$ using a digital caliper, and whole wet weight (W) was recorded to the nearest $0.1 \mathrm{~g}$ using an electronic balance. Although sex was recorded, the number of males sampled of each species was not enough to evaluate LWR parameters, so sex was not considered for further analyses.

Our main aim was to compare the length-weight relationships (LWR) of the three species across different places and time points in different climatic seasons (fall, winter, spring-summer). Generalized linear models (GLM) based on the Gamma distribution with the inverse link function were employed to explore the effects of the categorical predictors, sampling place and sampling season, and the explanatory variable, total length (TL, in $\mathrm{cm}$ ), on the response variable, wet weight (W, in $\mathrm{g}$ ). All data were included in these models, even if the sampling design was not fully crossed due to logistical constraints, which resulted in a zero degree of freedom for the interaction term (Table 1). GLM for the three species showed that LWR parameters were not affected by a two-way interaction between place and season, and also showed that season was not a significant term (Table 1). Therefore, the pattern for the entire sampling period for each species, and each place was examined by defining the length-weight relationship for the whole data set (common slope and intercept). In this sense, LWR were considered to follow growth models of the type $\mathrm{W}=a \times \mathrm{TL}^{b}$, where $a$ and $b$ are parameters.

Parameter estimation was conducted by leastsquares linear regression on $\log _{10}-\log _{10}$ transformed data; $\log _{10}(\mathrm{~W})=\log _{10}(a)+b \log _{10}(\mathrm{TL})$, where $b$ is the slope and $\log _{10}(a)$ the intercept (Froese, 2006). The coefficient of determination (Pearson r-squared, $\mathrm{R}^{2}$ ) was used as an indicator of the linear regression quality. The LWR is said to be isometric when $b=3$ (Froese
2006), so the $b$ value of each species was tested with the 2-tailed Student's t-test $(\alpha=0.05)$ to detect differences from the isometric value. The statistical significance, standard error (SE) for parameters $a$ and $b$ were also determined. The fitted parameters $[b$ and $\left.\log _{10}(a)\right]$ for a species occurring in different sampling sites were tested against each other using Welch's approximate $t$-test (Zar, 1999). Length-length relationships were also established using linear regression analysis: $\mathrm{TL}=a+b \times \mathrm{SL}$.

All analyses were performed using InfoStat software (Di Rienzo et al., 2018). This software implements an interface of the $\mathrm{R}$ platform version 3.4.1 ( $\mathrm{R}$ Core Team, 2017) to estimate generalized linear models through GLM and GLMER procedures from the stats and lme4 libraries (Bates et al., 2013).

The parameters found were compared with those recorded in the literature by other authors in the distribution range of each of the species.

A total of 2,167 specimens belonging to three species $(1,137$ for $O$. argentinensis, 570 for $U$. brasiliensis, and 460 for $B$. aurea) were collected in five sampling sites (Fig. 1). Table 2 summarizes LWR parameters showing the wide range of $\mathrm{LT}$ and $\mathrm{W}$ data used. The values for the allometric coefficient varied between 2.66 and 3.33. All relations were highly significant $(P<0.0001)$, and except for $B$. aurea, $\mathrm{R}^{2}$ values were higher than 0.94 , suggesting the robustness of coefficient estimates. According to FishBase data, the present work reports a new maximum TL $(41.5 \mathrm{~cm})$ for $B$. aurea, which was superior in $7.1 \mathrm{~cm}$ than what has been registered so far.

Table 2 shows that $O$. argentinensis (SB), $U$. brasiliensis (LL and MdP) and B. aurea (SB and LL) presented positive allometry $(b>3)$ (large specimens that have increased in height or width more than in length); O. argentinensis (LL) and U. brasiliensis (VG) presented isometry; the rest of the specimens showed negative allometry $(b<3)$. Moreover, fish that gave negative allometry (large specimens that have changed their body shape becoming more elongated or small) were in better nutritional condition at the time of sampling. $O$. argentinensis and $U$. brasiliensis presented either positive allometry or isometry, depending on the geographic area sampled. B. aurea presented both negative and positive allometries, which also depended on the area sampled. There was no latitudinal pattern for negative or positive allometry. Eight of the 10 comparisons among geographic areas were significant at $\alpha=0.05$ for both regression coefficients; only for B. aurea, there were no significant differences between the two places with negative allometry values and between the two sites with positive values (Table 3a-b). 


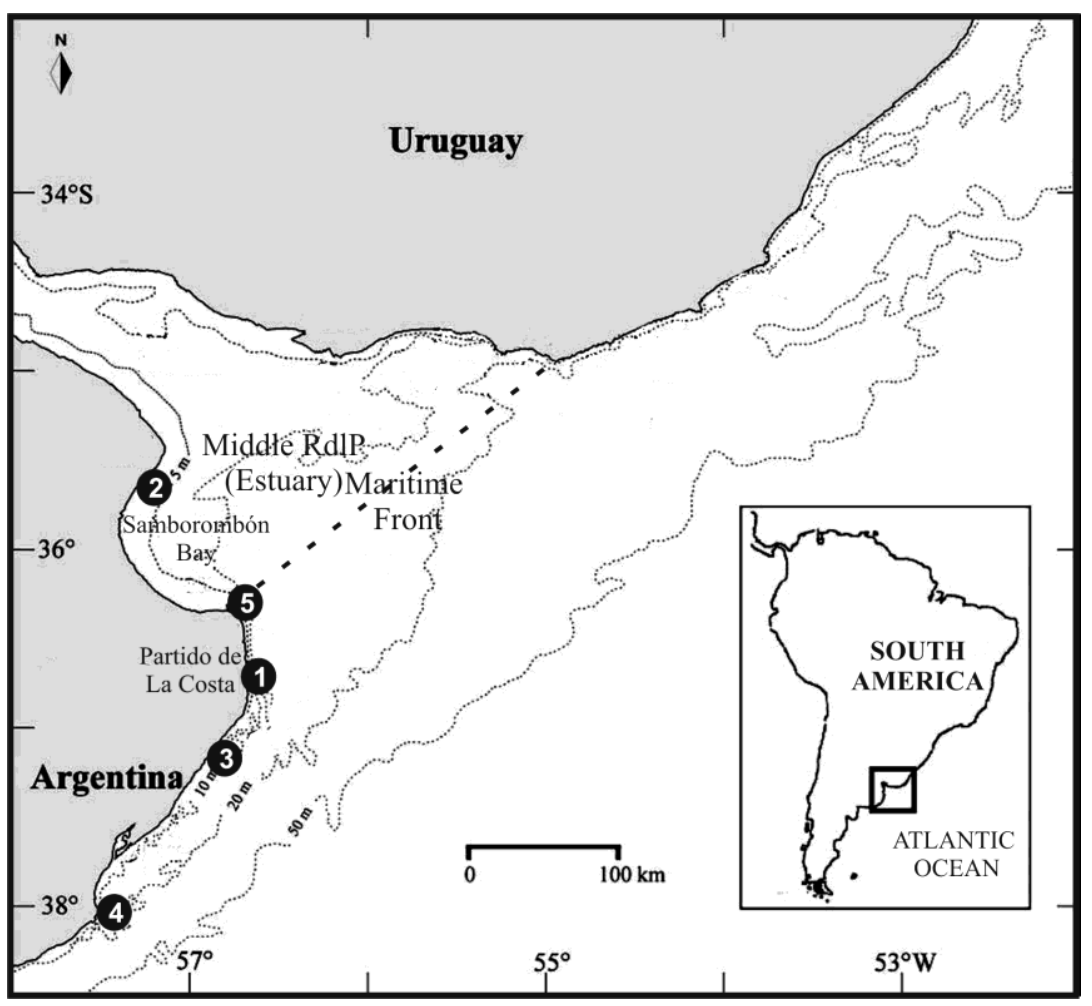

Figure 1. Geographic location of study place. 1) Lucila del Mar, 2) Samborombón Bay, 3) Villa Gesell, 4) Mar del Plata, and 5) San Clemente del Tuyú.

Table 1. Generalized linear model to test for differences in length-weight relationship in each species studied. $X^{2}$ values and degrees of freedom in brackets are shown for each fixed factor and their interaction. ${ }^{* * *} P<0.001 ;{ }^{+} P>0.05$.

\begin{tabular}{lccc}
\hline \multirow{2}{*}{ Species } & \multicolumn{3}{c}{ Factors } \\
\cline { 2 - 4 } & Place & Season & Place*Season \\
\hline Odontesthes argentinensis & $17.71^{* * *}(1)$ & $7.74^{+}(3)$ & $<0.01^{+}(0)$ \\
Urophycis brasiliensis & $2.92^{+}(2)$ & $7.08^{+}(3)$ & $<0.01^{+}(0)$ \\
Brevoortia aurea & $234.95^{* * *}(3)$ & $0.73^{+}(2)$ & $<0.01^{+}(0)$ \\
\hline
\end{tabular}

Table 4 summarizes LLR relationship parameters for each species, like in LWR, all relations were highly significant $(P<0.0001)$, and robust coefficients $\left(R^{2}\right)$ were determined.

The biological information associated with LWR parameters mostly for Brazilian and Uruguayan populations is limited, notwithstanding the wide distribution range of the three species (Table 5). Our study, together with reported parameters of the LWR for these three species (Table 5 and references therein), showed that $b$ values estimated for LWR remained within the expected range 2.5 and 3.5 for fish (Froese, 2006). The extreme $b$-values (>3.3) may be caused by the presence of only juveniles in the samples $(U$. brasiliensis at MdP and B. aurea at LL, Table 2), a situation which has also been reported by Passos et al. (2012). Moreover, these two species have been sampled only on one or two occasions (Table 5); thus, this fact could also be associated with the extreme $b$-values observed (Froese, 2006).

Our results, together with reported works, confirmed the existence of a strong interrelationship between both parameters suggested by Froese (2006). The interdependence resulted in a linearized relationship in a plot of $\log a$ over $b$ for the three species (Fig. 2a). The only exception to this linearized relationship was the parameters of $O$. argentinensis belonging to Samborombón Bay (not included in the estimation of the $\mathrm{R}^{2}$; Fig. 2). Froese (2006) indicated that this type of WLRs could be questionable because of sampling problems (narrow size range, few data with high variance, or outliers in the respective sample) and should be removed. However, our LWR parameters were almost the same reported by Solari et al. (2016) in 
Table 2. Descriptive statistics and estimated parameters of length-weight relationships for fish species collected from Argentine coastal waters. LL: Lucila del Mar; SB: Samborombón Bay; VG: Villa Gesell; MdP: Mar del Plata, and SCT: San Clemente del Tuyú. n: sample size; TL: total length; W: total body weight; $a$ : intercept; $b$ : the slope of the linear regression; SE: standard error; SD: standard deviation; $\mathrm{R}^{2}$ : coefficient of determination. *Significant 2-tailed Student's ttest, which indicated that $b=$ allometric. Bold: new maximum length.

\begin{tabular}{|c|c|c|c|c|c|c|c|c|}
\hline Species & $\mathrm{n}$ & $\begin{array}{c}\text { TL range }(\mathrm{cm}) \\
(\text { mean } \pm \mathrm{SD})\end{array}$ & $\begin{array}{l}\text { W range }(\mathrm{g}) \\
(\text { mean } \pm \mathrm{SD})\end{array}$ & $\log _{10} a$ & $\mathrm{SE}\left(\log _{10} a\right)$ & $b$ & $\mathrm{SE}(b)$ & $\mathrm{R}^{2}$ \\
\hline O. argentinensis (SB) & 174 & $\begin{array}{r}9.6-35.5 \\
(20.7 \pm 8.8)\end{array}$ & $\begin{array}{c}5-348 \\
(92.5 \pm 97.6)\end{array}$ & -2.475 & 0.027 & $3.203 *$ & 0.021 & 0.993 \\
\hline O. argentinensis (LL) & 963 & $\begin{array}{r}4.0-36.0 \\
(14.0 \pm 5.6)\end{array}$ & $\begin{array}{c}0.3-330 \\
(25.5 \pm 36.2)\end{array}$ & -2.225 & 0.009 & 3.004 & 0.009 & 0.992 \\
\hline U. brasiliensis (LL) & 50 & $\begin{array}{c}20-51 \\
(37.3 \pm 9.6)\end{array}$ & $\begin{array}{r}60-1141 \\
(538 \pm 332)\end{array}$ & -2.272 & 0.126 & $3.128 *$ & 0.080 & 0.969 \\
\hline U. brasiliensis $(\mathrm{MdP})$ & 221 & $\begin{array}{c}5.8-24.3 \\
(16.7 \pm 3.2)\end{array}$ & $\begin{array}{c}12-125 \\
(39.4 \pm 23.4)\end{array}$ & -2.538 & 0.025 & $3.336^{*}$ & 0.020 & 0.992 \\
\hline U. brasiliensis $(\mathrm{VG})$ & 299 & $\begin{array}{c}26.7-52 \\
(42.7 \pm 4.2)\end{array}$ & $\begin{array}{c}175-1365 \\
(726 \pm 204)\end{array}$ & -1.978 & 0.069 & 2.959 & 0.042 & 0.943 \\
\hline B. aurea $(\mathrm{SB})$ & 42 & $\begin{array}{c}32.6-41.5 \\
(36.5 \pm 2.5)\end{array}$ & $\begin{array}{c}265-945 \\
(467 \pm 131)\end{array}$ & -2.287 & 0.573 & $3.163 *$ & 0.366 & 0.642 \\
\hline B. aurea $(\mathrm{SCT})$ & 168 & $\begin{array}{c}24.2-41.4 \\
(34.6 \pm 3.7)\end{array}$ & $\begin{array}{c}160-917 \\
(446 \pm 139)\end{array}$ & -1.528 & 0.154 & $2.703 *$ & 0.100 & 0.813 \\
\hline B. aurea $(\mathrm{LL})$ & 104 & $\begin{array}{c}5.0-12.2 \\
(7.7 \pm 2.2)\end{array}$ & $\begin{array}{l}0.93-16 \\
(4.8 \pm 4.2)\end{array}$ & -2.376 & 0.035 & $3.306^{*}$ & 0.039 & 0.985 \\
\hline B. aurea $(\mathrm{MdP})$ & 146 & $\begin{array}{r}19.4-28.6 \\
(22.6 \pm 1.6)\end{array}$ & $\begin{array}{c}83-206 \\
(135 \pm 26.7)\end{array}$ & -1.491 & 0.096 & $2.668 *$ & 0.071 & 0.906 \\
\hline
\end{tabular}

Table 3a. Probabilities associated with Welch's approximate t-tests comparing slopes $b$ and intercepts $\ln (a)$ among sampling places (LL: Lucila del Mar; SB: Samborombón Bay; VG: Villa Gesell; MdP: Mar del Plata and SCT: San Clemente del Tuyú) for Odontesthes argentinensis and Urophycis brasiliensis.

\begin{tabular}{|c|c|c|c|c|}
\hline \multirow{2}{*}{ Species } & LL-SB & LL-VG & LL-MdP & MdP-VG \\
\hline & $\ln (a)$ & $b \quad \ln (a)$ & $\ln (a)$ & $\ln (a)$ \\
\hline $\begin{array}{l}\text { O. argentinensis } \\
U . \text { brasiliensis }\end{array}$ & $<0.0001<0.0001$ & $0.0001<0.0001$ & $<0.0001<0.0001$ & $<0.0001<0.0001$ \\
\hline
\end{tabular}

Table 3b. Probabilities associated with Welch's approximate t-tests comparing slopes $b$ and intercepts $\ln (a)$ among sampling places (LL: Lucila del Mar; SB: Samborombón Bay; VG: Villa Gesell; MdP: Mar del Plata and SCT: San Clemente del Tuyú) for Brevoortia aurea.

\begin{tabular}{|c|c|c|c|c|c|c|c|c|c|}
\hline \multirow{2}{*}{ Species } & \multicolumn{2}{|c|}{ LL-SB } & LL-MdP & LL-SCT & MdP-SB & $\mathrm{Md}$ & -SCT & \multicolumn{2}{|c|}{ SB-SCT } \\
\hline & $b$ & $\ln (a)$ & $\ln (a)$ & $\ln (a)$ & $\ln (a)$ & $b$ & $\ln (a)$ & $b$ & $\ln (a)$ \\
\hline B. aurea & 0.07 & 0.23 & $<0.0001<0.0001$ & $<0.0001<0.0001$ & $<0.0001<0.0001$ & 0.18 & 0.19 & $<0.0001$ & 0.0001 \\
\hline
\end{tabular}

the same area (Samborombón Bay; Table 5). This similarity suggested that our result could not be questionable, according to Froese's (2006) arguments; however, the significance of this fact remains to be elucidated and could be related to particularities of the environment (Rio de la Plata Estuary, Fig. 1).

Isometric growth registered for $O$. argentinensis agreed with the recorded data reported by Thompson \& Volpedo (2018) in the same place but only with summer samples. Other reports for this species from Brazil (Haimovici \& Velasco, 2000), Uruguay (Gurdek
\& Acuña, 2014), and Argentina (Molina, 2012; Llompart et al., 2013) suggested positive allometric growths. The latitudinal trend showed a bell-shaped curve type for $\log 10(a)$ (Fig. 2b) and an inverse bell curve type for $b$ (Fig. 2c). Positive allometric growth seemed to be related to the northern and southern evaluated distributional range (Fig. 2c). To the best of our knowledge, this is the first evidence of such a latitudinal gradient in $O$. argentinensis $b$ parameters of LWR. Positive allometric growth for $U$. brasiliensis was also suggested for Uruguay (Acuña \& Verocai, 2001; 
Table 4. Relationship between total length and the standard length of fishes collected from Argentine waters. n: sample size; TL: total length; SL: standard length; SD: standard desviation; $a$ : intercept; $b$ : the slope of the linear regression; CI: confidence limits; $\mathrm{R}^{2}$ : coefficient of determination.

\begin{tabular}{|c|c|c|c|c|c|c|}
\hline \multirow[b]{2}{*}{ Species } & \multirow[b]{2}{*}{$\mathrm{n}$} & \multirow{2}{*}{$\begin{array}{l}\text { TL range }(\mathrm{cm}) \\
(\text { mean } \pm S D)\end{array}$} & \multirow{2}{*}{$\begin{array}{c}\text { SL range }(\mathrm{cm}) \\
(\text { mean } \pm \mathrm{SD})\end{array}$} & \multicolumn{3}{|c|}{ L-L regression parameter } \\
\hline & & & & $a$ & $b$ & $\mathrm{R}^{2}$ \\
\hline Odontesthes argentinensis & 1137 & $\begin{array}{c}4.0-36.0 \\
(14.0 \pm 5.6)\end{array}$ & $\begin{array}{r}3.4-31.0 \\
(11.5 \pm 4.6)\end{array}$ & -0.029 & 1.222 & 0.999 \\
\hline Urophycis brasiliensis & 570 & $\begin{array}{c}5.8-52.0 \\
(32.2 \pm 13.3)\end{array}$ & $\begin{array}{c}5.0-46.0 \\
(27.7 \pm 11.7)\end{array}$ & 0.948 & 1.127 & 0.995 \\
\hline Brevoortia aurea & 146 & $\begin{array}{c}5.0-41.5 \\
(16.0 \pm 13.3)\end{array}$ & $\begin{array}{r}4.1-32.0 \\
(12.5 \pm 9.9)\end{array}$ & -0.633 & 1.335 & 0.991 \\
\hline
\end{tabular}

Table 5. Spatial, temporal location, frequency of sampling, number of individuals (n), minimum and maximum lengths $(\mathrm{cm})$ and parameters of the length-weight and length-length relationships for three species in this study and values reported for previous studies. ND: No Data.

\begin{tabular}{|c|c|c|c|c|c|c|c|c|c|}
\hline \multicolumn{10}{|l|}{ Odontesthes argentinensis } \\
\hline Place & Lat. range & Time range & Freq. & LT range & $\mathrm{n}$ & $\log (a)$ & $b$ & $\mathrm{R}^{2}$ & Reference \\
\hline Lucila Mar, Argentina & $36^{\circ} 30^{\prime} \mathrm{S}$ & $2015-2017$ & Bimonthly & $4-36$ & 963 & -2.2259 & 3.00 & 0.992 & 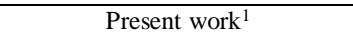 \\
\hline Samborombón Bay, Argentina & $35^{\circ} 30^{\prime} \mathrm{S}$ & $08 / 17-08 / 18$ & Aug (3 samplings) & $9.6-35.5$ & 174 & -2.4756 & 3.20 & 0.993 & Present work $^{2}$ \\
\hline Lucila Mar, Argentina & $36^{\circ} 30^{\prime} \mathrm{S}$ & 2013-2014 & Summer & $4.5-35$ & 595 & -2.2218 & 3.01 & 0.991 & Thompson \& Volpedo $(2018)^{\mathrm{A}}$ \\
\hline Anegada Bay, Argentina & $40-41^{\circ} \mathrm{S}$ & 06/08-05/09 & Monthly & $16.1-44.1$ & 876 & -2.5086 & 3.13 & 0.950 & Llompart et al. $(2013)^{\mathrm{B}}$ \\
\hline Anegada Bay, Argentina & $41^{\circ} \mathrm{S}$ & 2008 & Autum & $12-37.6$ & 138 & -2.7375 & 3.22 & 0.960 & Molina $(2012)^{\mathrm{C}}$ \\
\hline Pando, Uruguay & $34^{\circ} 47^{\prime} \mathrm{S}$ & $05 / 02-06 / 03$ & Monthly & $3.2-42$ & 74 & -2.2848 & 3.06 & 0.991 & Gurdek \& Acuña $(2014)^{\mathrm{D}}$ \\
\hline Rio Grande, Brazil & $28^{\circ}-34^{\circ} \mathrm{S}$ & $1975-1994$ & Yearly & $2.8-42.1$ & 53 & -2.3858 & 3.07 & 0.992 & Haimovici \& Velasco $(2000)^{\mathrm{E}}$ \\
\hline Place & Lat. range & Time range & Freq. & SL range & $\mathrm{N}$ & $\log (a)$ & $b$ & $\mathrm{R}^{2}$ & Reference \\
\hline Samborombón Bay, Argentina & $35^{\circ} 30^{\prime} \mathrm{S}$ & $08 / 17-08 / 18$ & Aug (3 samplings) & $8-31$ & 174 & -2.1800 & 3.18 & 0.992 & ${\text { Present } \text { work }^{2}}^{2}$ \\
\hline Samborombón Bay, Argentina & $36^{\circ} \mathrm{S}$ & 09/07-08/09 & Bimonthly & $2.5-24.8$ & 279 & -2.1800 & 3.23 & 0.99 & Solari et al. (2016) \\
\hline \multicolumn{10}{|l|}{ Urophycis brasiliensis } \\
\hline Lucila Mar, Argentina & $36^{\circ} 30^{\prime} \mathrm{S}$ & 2013-2016 & 6 Samplings & $20-51$ & 50 & -2.2720 & 3.13 & 0.969 & Present work ${ }^{1}$ \\
\hline Villa Gesell, Argentina & $37^{\circ} \mathrm{S}$ & $10 / 15-10 / 18$ & Yearly & $26.7-52$ & 300 & -1.9781 & 2.96 & 0.943 & Present work ${ }^{3}$ \\
\hline Mar Del Plata, Argentina & $38^{\circ} \mathrm{S}$ & 2018 & July & $5.8-24.3$ & 220 & -2.5382 & 3.34 & 0.992 & Present work $^{4}$ \\
\hline La Paloma, Uruguay & $35^{\circ} \mathrm{S}$ & 1984-1994 & ND & $22.6-51.2$ & 1506 & -2.3261 & 3.13 & 0.967 & Acuña \& Verocai $(2001)^{\mathrm{F}}$ \\
\hline Punta Diablo, Uruguay & $33^{\circ} 54^{\prime}-34^{\circ} 04^{\prime}$ & 2006-2010 & ND & $4.8-52.2$ & 867 & -2.5229 & 3.22 & 0.970 & Segura et al. $(2012)^{\mathrm{G}}$ \\
\hline Ubatuba, Brazil & $26^{\circ} 11^{\prime} \mathrm{S}$ & $10 / 03-09 / 04$ & Monthly & $4.3-18.9$ & 20 & -2.0458 & 2.91 & 0.959 & Freitas et al. $(2011)^{\mathrm{H}}$ \\
\hline Southern Brazil & $22-35^{\circ} \mathrm{S}$ & 1997-1998 & ND & $18-63$ & 515 & -2.1494 & 3.02 & 0.970 & Andrade et al. $(2005)^{\mathrm{I}}$ \\
\hline Parana, Brazil & $25^{\circ}$ & 08/04-07/05 & Monthly & $5-16.1$ & 74 & -2.3665 & 3.14 & 0.978 & Passos et al. $(2012)^{\mathrm{J}}$ \\
\hline Sao Paulo, Brazil & $23^{\circ} 30^{\prime}-24^{\circ}$ & 1993-1995 & 5 Samplings & $9-53.2$ & 51 & -2.3261 & 3.15 & 0.984 & Muto et al. $(2000)^{\mathrm{K}}$ \\
\hline Rio Grande, Brazil & $28^{\circ}-34^{\circ} \mathrm{S}$ & $1975-1994$ & Yearly & $8.7-58.6$ & 252 & -2.4001 & 3.21 & 0.982 & Haimovici \& Velasco $(2000)^{\mathrm{E}}$ \\
\hline Rio Grande, Brazil & $30^{\circ} \mathrm{S}$ & $1990-1993$ & ND & ND & 2763 & -2.4802 & 3.25 & ND & Haimovici \& Mendonca $(1996)^{\mathrm{L}}$ \\
\hline Southeastern, Brazil & $23^{\circ} 18^{\prime}-23^{\circ} 58^{\prime} \mathrm{S}$ & 1995-1996 & ND & $5-42$ & 16 & -2.7959 & 3.47 & 0.994 & Vianna et al. $(2004)^{\mathrm{M}}$ \\
\hline \multicolumn{10}{|l|}{ Brevoortia aurea } \\
\hline Lucila Mar, Argentina & $36^{\circ} 30^{\prime} \mathrm{S}$ & 2016 & Mar and Dic & $5-12.2$ & 104 & -2.3762 & 3.31 & 0.985 & 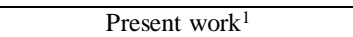 \\
\hline Samborombón Bay, Argentina & $36^{\circ} \mathrm{S}$ & $2016-2017$ & Mar and Sep (2 sampl.) & $32.6-41.5$ & 42 & -2.2868 & 3.16 & 0.65 & Present work ${ }^{2}$ \\
\hline Mar Del Plata, Argentina & $38^{\circ} \mathrm{S}$ & 2018 & Feb & $19.4-28.6$ & 146 & -1.4907 & 2.67 & 0.907 & Present work ${ }^{4}$ \\
\hline San Clemente Tuyú, Argentina & $36^{\circ} 21^{\prime} \mathrm{S}$ & 2018 & January & $24.2-41.4$ & 168 & -1.5278 & 2.70 & 0.814 & Present work ${ }^{5}$ \\
\hline Pando, Uruguay & $34^{\circ} 47^{\prime} \mathrm{S}$ & $05 / 02-06 / 03$ & Monthly & $3-34.4$ & 113 & -2.0250 & 3.05 & 0.995 & Gurdek \& Acuña $(2014)^{\mathrm{D}}$ \\
\hline Southern Brazil & $22^{\circ} 50 ' \mathrm{~S}$ & 2011 & Feb-Aug & $1.9-12$ & 1467 & -2.2218 & 3.11 & 0.980 & Franco et al. $(2014)^{\mathrm{N}^{\prime}}$ \\
\hline Place & Lat. range & Time range & Freq. & SL range & $\mathrm{n}$ & $\log (a)$ & $\mathrm{b}$ & $\mathrm{R}^{2}$ & Reference \\
\hline Samborombón Bay, Argentina & $36^{\circ} \mathrm{S}$ & $2016-2017$ & Mar and Sep (2 sampl.) & $24.5-32$ & 42 & -1.2215 & 2.69 & 0.51 & Present work $^{2}$ \\
\hline Samborombón Bay, Argentina & $36^{\circ} \mathrm{S}$ & 09/07-08/09 & Bimonthly & $2.6-7.3$ & 387 & -2.1300 & 3.46 & 0.99 & Solari et al. (2016) \\
\hline
\end{tabular}



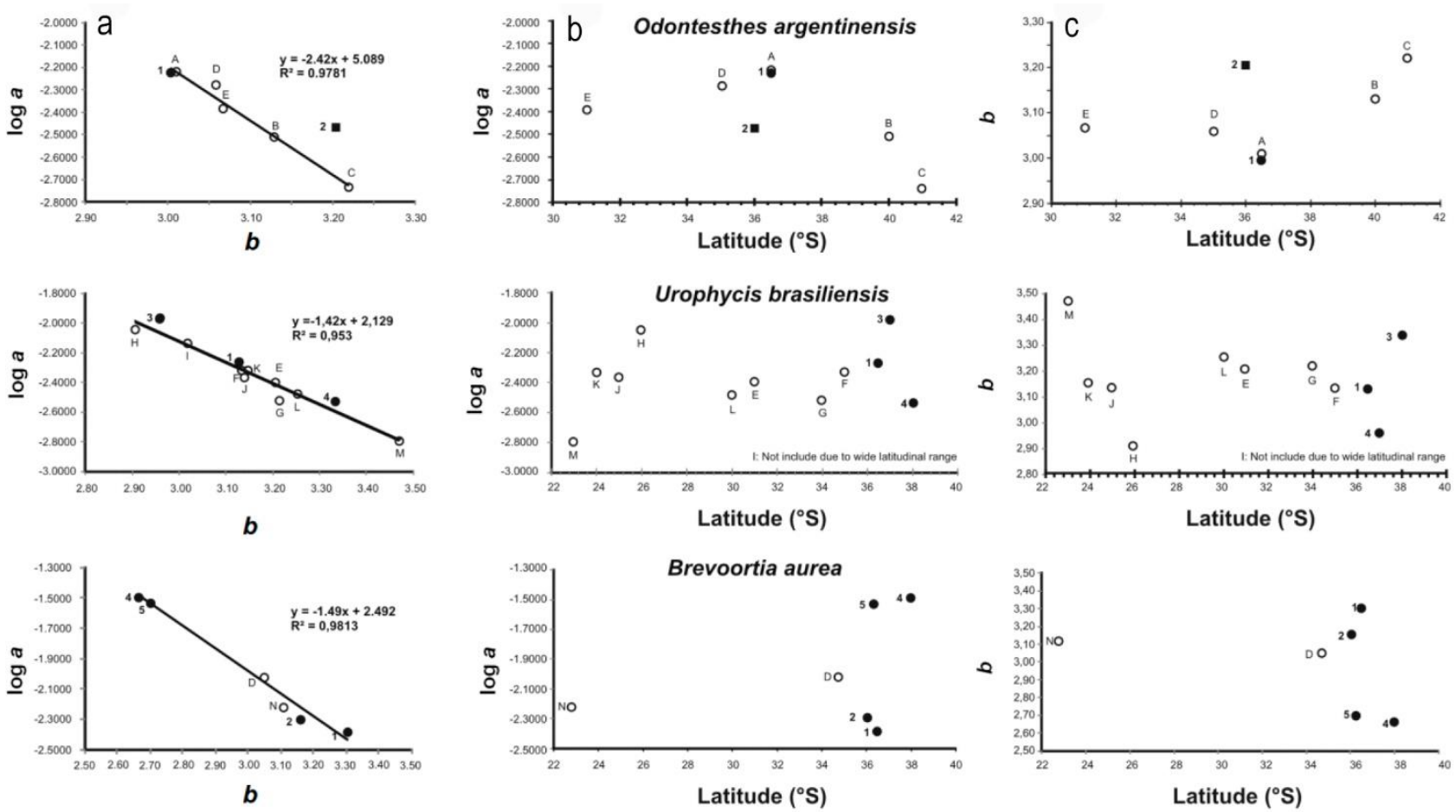

Figure 2. a) Plot of $\log a$ over $b$ for weight-length relationships, b) plot of $\log a$ with respect to latitude, c) plot of $b$ with respect to latitude. Locality: 1 Lucila del Mar, 2 Samborombón Bay, 3 Villa Gesell, 4 Mar del Plata, 5 San Clemente del Tuyu. References, A: Thompson \& Volpedo (2018) (Lucila del Mar, Argentina); B: Llompart et al. (2013) (Bahía Anegada, Argentina); C: Molina (2012) (Bahía Anegada, Argentina); D: Gurdek \& Acuña (2014) (Pando, Uruguay); E: Haimovici \& Velasco (2000) (Rio Grande, Brazil); F: Acuña \& Verocai (2001) (La Paloma, Uruguay); G: Segura et al. (2012) (Punta Diablo, Uruguay); H: Freitas et al. (2011) (Ubatuba, Brazil); I: Andrade et al. (2005) (southern Brazil); J: Passos et al. (2012) (Parana, Brazil); K: Muto et al. (2000) (Sao Paulo, Brazil); L: Haimovici \& Mendonça (1996) (Rio Grande, Brazil); M: Vianna et al. (2004) (southeastern Brazil); N: Franco et al. (2014) (southwestern Brazil).

Segura et al., 2012) and Brazil (Haimovici \& Mendonça, 1996; Haimovici \& Velasco, 2000; Muto et al., 2000; Vianna et al., 2004; Passos et al., 2012) populations. Also, isometric and negative allometric growth has been reported in Brazil (Andrade et al., 2005 and Freitas et al., 2011, respectively). The latitudinal trend of $a$ and $b$ did not show any patterns, except for a tendency to a latitudinal decrease (increase) of $b$ values in the northern (southern) latitudinal range (Fig. 2c). Negative allometric growth is recorded for $B$. aurea for the first time in the present work, since previous records suggested positive allometric growth for Brazil (Franco et al., 2014), Uruguay (Gurdek \& Acuña-Plavan, 2014) and Argentinian waters (Solari et al., 2016). The latitudinal trend of $a$ and $b$ did not show any patterns (Figs. 2b-c).

It should be acknowledged that LWR parameters could be affected by several factors such as differences in the sample size, length range, growth phase, sex, gonadal maturity, fishing gears, seasonality and variation in salinity, temperature and food (Haimovici \&
Velasco, 2000; Froese 2006; Solari et al., 2016). However, the analysis of the influence of these factors is beyond the purpose of this report. To our knowledge, there are no previous reports on LLR for this marine fish species.

The present work contributes reliable morphometric relationships for three marine fish species of great commercial, artisanal and recreational importance in the southwestern Atlantic Ocean.

Finally, this study provides additional information on the southwestern Atlantic Ocean ichthyofauna, contributing to important basic data for regional sustainable fisheries management.

\section{ACKNOWLEDGMENTS}

We acknowledge CONICET (PUE 229201801000 47CO), Universidad de Buenos Aires (UBACYT 20020150100052BA), and the Agencia Nacional de Promoción Científica y Técnica (ANPCyT PICT 2015- 
1823 ) for financial support. We are grateful to Alejandro Ferrin, to Hugo Urbina (Lucila del Mar), to Andrés Milessi of Instituto Nacional de Investigación y Desarrollo Pesquero (INIDEP), to Club de Pesca, Caza y Náutica de Villa Gesell, to parkrangers of Buenos Aires Province (OPDS) for their collaboration with the samples. Finally, we thank reviewers and the editor for their constructive and helpful reviews.

\section{REFERENCES}

Acuña, A. \& Verocai, J.E. 2001. Importancia de la pesquería artesanal y biología de la brótola, Urophycis brasiliensis (Kaup, 1858) (Phycidae, Gadiformes) en la costa uruguaya. Investigaciones Marinas, 29(1): 4758.

Andrade, H.A., Lucato, S.H.B \& Soares, G.S. 2005. Urophycis brasiliensis (Kaup, 1858). Análise das principais pescarias comerciais da região sudeste-sul do Brasil: dinâmica populacional das espécies em explotação. Universidade de São Paulo, Série Documentos REVIZEE-Score Sul, Boletim do Instituto Oceanográfico, pp. 167-172.

Bates, D., Maechler, M., Bolker, B. \& Walker, S. 2013. lme4: linear mixed-effects models using Eigen and S4. $\mathrm{R}$ package version 1.0-5. [http://CRAN.R-project.org/ package=lme4]. Reviewed: March 11, 2019.

Bovcon, N.D., Cochia, P.D., Góngora, M.E. \& Gosztonyi, A.E. 2011. New records of warm-temperate water fishes in central Patagonian coastal waters (southwestern South Atlantic Ocean). Journal of Applied Ichthyology, 27: 832-839. doi: 10.1111/j.1439-0426. 2010.01594.x

Di Dario, F., Dos Santos, V.M. \& De Souza-Pereira, M.M. 2014. Range extension of Odontesthes argentinensis (Valenciennes, 1835) (Teleostei: Atherinopsidae) in the southwestern Atlantic, with additional records in the Rio de Janeiro State, Brazil. Journal of Applied Ichthyology, 30: 421-423. doi: 10.1111/jai.12393

Di Rienzo, J.A., Casanoves, F., Balzarini, M.G., Gonzalez, L., Tablada, M. \& Robledo, C.W. 2018. InfoStat versión 2018. Grupo InfoStat, FCA, Universidad Nacional de Córdoba, Córdoba. [http://www. infostat.com.ar]. Reviewed: March 15, 2019.

Dyer, B.S. 2000. Revisión sistemática de los pejerreyes de Chile (Teleostei, Atheriniformes). Estudios Oceanológicos, 19: 99-127.

Franco, T.P., Araújo, C.E.O \& Araújo, F.G. 2014. Lengthweight relationships for 25 fish species from three coastal lagoons in southeastern Brazil. Journal of Applied Ichthyology, 30(1): 248-250. doi: 10.1111/ jai.12271
Freitas, M.O., Machado-Vasconcelos, S., Hostim-Silva, M. \& Spach, H.L. 2011. Length-weight relationships for fishes caught by shrimp trawl in Santa Catarina coast, south Atlantic, Brazilian. Journal of Applied Ichthyology, 27(6): 1427-1428. doi: 10.1111/j.14390426.2009.01220.x

Froese, R. 2006. Cube law, condition factor and weightlength relationships: history, meta-analysis and recommendations. Journal of Applied Ichthyology, 22: 241253. doi: 10.1111/j.1439-0426. 2006.00805.x

Gurdek, R. \& Acuña-Plavan, A. 2014. Weight-length relationships of 12 fish species from the Pando tidal creek estuary (subsystem of the Río de la Plata, Uruguay). Journal of Applied Ichthyology, 30: 426427. doi: $10.1111 /$ jai.12241

Haimovici, M. \& Mendonça, J.T. 1996. Descartes da fauna acompanhante na pesca de arrastro de tangones dirigida a linguados e camarões na plataforma continental do sul do Brasil. Atlântica, 18: 161-177.

Haimovici, M. \& Velasco, G. 2000. Length-weight relationship of marine fishes from southern Brazil. Naga, 23: 19-23.

Lemes, P.C., Loeb, M.V., Santificetur, C. \& Melo, M.R. 2016. Redescription of Urophycis brasiliensis (Kaup 1858), a senior synonym of Urophycis latus Miranda Ribeiro 1903 (Gadiformes: Phycidae). Zootaxa, 4084(4): 507-518.

Llompart, F.M., Colautti, D.C., Maiztegui, T., CruzJiménez, A.M. \& Baigún, C.R.M. 2013. Biological traits and growth patterns of pejerrey Odontesthes argentinensis. Journal of Fish Biology, 82(2): 458474. doi: 10.1111/j.1095-8649.2012.03494.X

Ma, Q., Jiao, Y. \& Ren, Y. 2017. Linear mixed-effects models to describe length-weight relationships for yellow croaker (Larimichthys polyactis) along the north coast of China. Plos One, 12(2): e0171811. doi: 10.1371/journal.pone.0171811

Menni, R.C., Ringuelet, R.A. \& Arámburu, R.H. 1984. Peces marinos de la Argentina y Uruguay. Hemisferio Sur, Buenos Aires.

Molina, J.M. 2012. La comunidad íctica de Bahía Anegada: estructura, composición, dinámica estacional y aspectos biológicos. Doctoral Disertation Thesis. Universidad Nacional del Sud, Bahía Blanca. [http://repositoriodigital.uns.edu.ar/handle/12345678 9/2734]. Reviewed: March 15, 2019.

Muto, E.Y. Soares, L.S.H. \& Rossi-Wongtschowski, C.L.D.B. 2000. Length-weight relationship of marine fish species off São Sebastião system, São Paulo, southeastern Brazil. Naga, 23(4): 27-29.

Nelson, J.S. (Ed.). 1994. Fishes of the world. Wiley and Sons, New York.

Passos, A.C., Schwarz Jr., R., Cartagena, B.F.C., Garcia, A.S. \& Spach, H.L. 2012. Weight-length relationship 
of 63 demersal fishes on the shallow coast of Paraná, Brazil. Journal of Applied Ichthyology, 28(5): 845847. doi: 10.1111/j.1439-0426.2012.01973.x

R Core Team. 2017: A language and environment for statistical computing. R Foundation for Statistical Computing. [https://www.R-project.org]. Reviewed: March 11, 2019.

Segura, V. \& Díaz de Astarloa, J.M. 2004. Análisis osteológico de la saraca Brevoortia aurea (Spix) (Actinopterygii: Clupeidae) en el Atlántico suroccidental. Revista de Biología Marina y Oceanografía, 39(2): 37-52.

Segura, A.M., Trinchin, R., Rabellino, J., Scarabino, F., Teixeira-De Mello, F. \& Carranza, A. 2012. Lengthweight relationships of 14 coastal fish species from Punta del Diablo (Rocha, Uruguay). Journal of Applied Ichthyology, 28(5): 852-853. doi: 10.1111/ j.1439-0426.2012.02011.x

Received: 28 May 2019; Accepted: 10 February 2020
Solari, A., Jaureguizar, A.J., Milessi, A.C., García, M.L. \& Maiztegui, T. 2016. Length-weight relationships of 29 species of teleost fish from shallow estuarine environment of Samborombon Bay (Rio de la Plata, Argentina). Universidade de São Paulo, Boletim do Instituto Oceanográfico, 42(1): 236-240. doi: 10.5007/ 1678-2305.2016v42n1p236

Thompson, G.A. \& Volpedo, A.V. 2018. Diet composition and feeding strategy of the new world silverside Odontesthes argentinensis in a temperate coastal area (South America). Marine and Coastal Fisheries: Dynamics, Management, and Ecosystem Science, 10: 80-88. doi: 10.1002/mcf2.10005

Vianna, M., Costa, F.E.S. \& Ferreira, C.N. 2004. Lengthweight relationship of fish caught as by-catch by shrimp fishery in the southeastern coast of Brazil. Universidade de São Paulo, Boletim do Instituto Oceanográfico, 30(1): 81-85.

Zar, J.H. 1999. Biostatistical analysis. Prentice-Hall, New Jersey. 